\title{
The Uncertainty Index and Foreign Direct Real Estate Investments in Developing Economies
}

\author{
Haydar Karadag ${ }^{1 *}$ \\ ${ }^{I}$ Faculty of Economics and Administrative Sciences, Recep Tayyip Erdogan University, Rize, Turkey
}

\begin{abstract}
Attainment of standards in a country's real estate market to meet international investors' expectations contributes significantly to the real estate sector. However, in developing economies characterized by an environment of uncertainty where stability cannot be achieved, direct investments in real estate can bring returns to foreign investors. This is because economic uncertainty in developing countries raises the exchange rate. An increase in the exchange rate keeps real estate prices in developing countries relatively low. Foreign investors then take advantage of the low prices to invest in real estate in that country. The study aims to research whether the uncertainty in developing countries increases the foreign direct real estate investments. The study examines the relationship between the uncertainties in selected developing economies in Europe and the real estate investments by foreigners in the period 2008-2018. Gengenbach, Urbain, and Westerlund Panel Cointegration test and PDOLS coefficient estimation methods were used in the study. According to the analysis results, a $1 \%$ increase in the uncertainty index in the economies examined increases foreign direct investments by $5.731 \%$. Since this study is one of the most detailed studies measuring foreign direct real estate investments under uncertainty conditions in the economy, it contributes to the literature. To sustainably increase foreigners' direct real estate investments in developing countries, economic and political stability should be prioritized. Facilitating the bureaucratic process, providing tax reductions, making real estate suitable for demand, following the appropriate price policy, and making various environmental regulations will also increase foreigners' direct real estate investments.
\end{abstract}

\section{Keywords:}

Uncertainty Index;

Foreign Direct Real Estate Investment;

Developing Economies;

PDOLS Coefficient Estimate Method.

$\begin{array}{lrll}\text { Article History: } & & \\ \text { Received: } & 16 & \text { April } & 2021 \\ \text { Revised: } & 11 & \text { June } & 2021 \\ \text { Accepted: } & 21 & \text { June } & 2021 \\ \text { Published: } & 01 & \text { August } & 2021\end{array}$

\section{1- Introduction}

While globalization created a common economic market in the world, it brought global social dynamism. This process has revealed the phenomenon of global citizenship. Thus, people have the opportunity to be citizens of the countries they live in while being within a wider community. However, the question is: Has the global world, in which citizenship is intended, caused the uncertainty? [1]. The answer to this question varies according to the development levels of the economies. The level of uncertainty in developing economies is higher than that in developed economies.

Along with globalization, developments in technology, science, and transportation made people more accessible to travel. This situation has influenced the development of tourism. Visits that started with touristic purposes, especially coastal settlements, have become permanent, increasing property acquisition by tourists [2]. With the globalization process, immovables have become international; capital and finance [3]. Foreign investors consider whether the real estate they will invest in is located on the country's coastline with mild climate characteristics, accessible transportation, and natural, historical, and cultural beauties [2]. For tourists residing in a touristic city, the cost of buying a timeshare or

* CONTACT: haydar.karadag@erdogan.edu.tr

DOI: http://dx.doi.org/10.28991/esj-2021-01293

(C) 2021 by the authors. Licensee ESJ, Italy. This is an open access article under the terms and conditions of the Creative Commons Attribution (CC-BY) license (https://creativecommons.org/licenses/by/4.0/). 
residence is much lower than hotel accommodation. For this reason, foreigners prefer to purchase real estate in the countries they settle in [4]. Additionally, the country's provision of high-quality, affordable health services to foreign investors fosters an increase in foreign direct real estate investments in the country [2].

Determination of the exchange rate in economies based on the supply and demand in the market facilitates comparison of price levels between countries. The need for hot money in terms of the balance of payments by economies causes sudden fluctuations in exchange rates. This situation adversely affects foreign trade and the real estate sector [2]. Moreover, changes in exchange rates cause inflation uncertainty. In an environment of inflation uncertainty, investors invest in real estate as a security factor to prevent the depreciation of their capital [5]. However, real estate price bubbles, which can occur even when controlling inflation, damage financial stability by disrupting financial institutions' balance. The real estate price bubbles adversely affect the functioning of the real economy by increasing household consumption and borrowing [6]. For example, it was observed that the Global Financial Crisis in 2008 and economic policy uncertainties negatively affected economic indicators at the micro and macro scales [7].

Economic agents face inflation uncertainty and political uncertainty, economic policy uncertainty, demand uncertainty, and cost uncertainty in economies. Internal factors such as wars, fluctuations in oil prices, and panics in international capital markets or increased volatility during an economic crisis also create uncertainty. Uncertainties in the economy affect the economic decisions of governments, firms, and households [7]. Investors avoid taking risks because of the uncertainties in the economy. In an uncertain environment where stability cannot be achieved, investments decrease and economies shrink. Speculative investments are seen in countries with economic uncertainty, and fixed capital investments in these countries remain low [8]. In this context, developing economies with high economic uncertainties are significantly affected by global economic policies. Therefore, foreign investors in the real estate sector in these countries also reconsider their investment decisions [9].

However, under high economic uncertainty in developing countries, foreign capital leaves reducing the amount of foreign currency in the country. Thus, the exchange rate in the economy rises. As the exchange rate increases in developing countries, the price of real estate remains relatively low compared to that in other developed countries. Foreign investors become more willing to take advantage of the relatively low real estate prices to buy real estate in that country. Thus, relatively low real estate prices enable foreigners to increase their direct real estate investments in developing countries.

Bringing the country's real estate market to standards that will meet international real estate investors' expectations significantly contributes to the country's real estate sector [3]. Foreigners consider essential, the characteristics such as the social-economic situation, political stability, and security of the countries in which they intend to invest in real estate. Changes in real estate prices are also crucial for foreign investors who evaluate decisions based on forward-looking predictions. Therefore, the money that the foreign investor will spend on real estate against foreign currency will affect the real estate investment of foreigners [10]. Changes in exchange rates in economies affect inflation uncertainty; inflation uncertainty affects the level of economic uncertainty. The change in the level of uncertainty in economies affects foreigners' real estate investment.

The study aims to investigate whether uncertainties in developing economies affect foreigners' real estate investments either positively or negatively. In this section, the relationship between real estate investments in foreigners and the uncertainty index is analyzed.

The study consists of 4 sections after the introduction. In the second section, information is given about the studies examining the variables in the literature that affect foreigners' real estate investments. In section 3, the methodology of the study is presented. In the section 4 the relationship between real estate investments in foreigners and the uncertainty index in selected emerging economies is analyzed and discussed. Analysis findings are interpreted in the conclusion section, which is the 5 th section.

\section{2- Literature Review}

Researches about real estate investments made by foreigners in economies have been noted. In integrated markets, capital flows to the countries that provide the highest revenue [11]. Regarding real estate investments by foreigners, Gerlowski et al. [12] examined investors' location preferences among Canada, Japan, and the UK for real estate firms in the USA. The analysis used a random effect model that combined time-series and cross-sectional data for 19801989. As a result, they found that foreigners preferred to invest in large developed and active economies. Cheng et al. [13] used Monte Carlo simulation in an environment of uncertainty in the US, UK, and Japan economies in 19731994. As a result, they found that while real estate promised to be a potential investment for foreign investors although it did not provide significant opportunities for investment diversification. In the USA, Miles [14] employed the data from 1975 to the third quarter of 2006 . He shows that uncertainty negatively impacts housing starts by using Modern Generalized Autoregressive Conditional Heteroskedasticity. According to Rodriguez and Bustillo [15], foreign real estate investment in Spain represents about $40 \%$ of total foreign direct investment inflows. In this regard, they are 
modeling foreign real estate investment for Spain in terms of demand for tourism services and financial focus, using time series data from 1990 to 2007. As a result, they found that the economic stagnation and decline in housing prices in Spain harmed direct real estate investment inflows.

Fereidouni and Bazrafshan [16] analyzed the determinants of housing returns in Iran by analyzing capital appraisals, rents, and total returns. Using the generalized method of moments (GMM) data from 2000-2007 in Iran's 28 provinces, Fereidouni and Bazrafshan investigated the determinants of housing returns in Iran. Findings show that real estate investors in Iran can earn higher returns if they invest in provinces with positive changes in population, GDP, inflation, and negative unemployment rate changes. Salem and Baum [17] reveal the main determinants of foreign direct investment in real estate in selected Middle East and North Africa (MENA) countries. The study used the pooled Tobit model techniques for data on the foreign direct investments (FDI) in the commercial real estate sector in the period 2003-2009 in Algeria, Egypt, Morocco, Qatar, Saudi Arabia, Turkey, Tunisia, and the UAE. Ultimately, Salem and Baum [19] found that some selected MENA countries attracted more commercial real estate investment than other MENA countries. In their article, Rogers and Koh [18] presented various case studies on global foreign housing investments from Canada, Hong Kong, Singapore, Russia, Australia, and Korea. They concluded that globalizing real estate had become an asset for foreign investors seeking to diversify their investment portfolio. Şit [19] examined essential factors impacting foreign real estate investment (FDIRE) in the Turkish economy. He employed a DOLSFMOLS estimator model to research the determinants of FDIRE in Turkey. Compared to 2003:Q1-2018:Q2 results, the opening up of the Turkish economy to the outside increases foreign investment in the real estate market.

International real estate investment takes place in economies according to exchange rate levels. According to Johnson et al. [20], international real estate investment is susceptible to exchange rate fluctuations. In the study, Johnson et al. [20] used Monte Carlo analysis for London from 1987 to 2003. As a result, the currency swap strategy reduces downside risk in currency fluctuations. Thus, the risk-adjusted exchange rate provides a significant return on international real estate investment. Dapaah and Hwee [21] reviewed the statistical significance of exchange rate risk on the return of international real estate investments in their study. From 1986 to 2007, Dapaah and Hwee [21] used Markowitz's average variance approach in seven Asia Pacific cities; they found that foreign exchange risk has a statistically significant positive effect on the returns of the office investment portfolio. Choi and Park [22] postulate that the adoption of the Euro will increase the volume of Foreign Direct Investment (FDI) in the real estate industry between Germany and European countries. To estimate the impact of the Euro on FDI in the real estate industry, they used a modified weight equation, Pooled OLS, and random-effects models. Their results from panel data from 34 countries over the period 1986-2009 showed that the Euro contributed to the bilateral increase in FDI in European countries' real estate industry.

Foreign real estate investors invest according to the real estate prices in the economy they want to invest in. In this context, Fereidouni and Masron [23] examined the effects of real estate market factors on foreign real estate investment (FREI) using the panel data technique; they explored the relationships between real estate market factors and FREI for 31 countries between 2000 and 2008. The results showed that lower financing costs and higher levels of transparency in the real estate market attracted more significant amounts of FREI to the countries studied. The article also revealed that foreign real estate investors prefer countries with higher property prices. Fereidouni et al. [24] analyzed the relationship between interest rate and inflation between FDI, economic growth, and property prices in the real estate sector; they examined OECD countries from 1995 to 2008 by applying the Dynamic reciprocal relationship, a panel cointegration technique. Empirical results showed that real estate FDI does not cause appreciation of property prices and does not contribute to short and long-term economic growth in OECD countries. Wokker and Swieringa [25] used fixed effects panel regression techniques to estimate the impacts of foreign demand for Australian residential real estate on property prices. According to their results, the supply of residential properties was fixed in the short term between July 2010 and March 2015.

Moreover, any increase in demand, whether domestic or foreign, leads to higher house prices. Rogers et al. [26] conducted a survey of perceptions on foreign and Chinese investment among over 900 Sydney residents in 2009_-2015. They found that foreign investment, especially by the Chinese, caused high levels of public anxiety and discontent among Sydney residents. The high house prices in Sydney also cause widespread concerns about housing affordability.

Uncertainties in economies affect macroeconomic variables. Similarly, uncertainties in economies have an impact on house prices and housing returns. Accordingly, Özdemir and Sayg1l [27] investigated whether macroeconomic uncertainty causes instability in traditional money demand models. The results of the VAR analysis for Turkey for the period 1992Q1 - 2008Q3 revealed stable relationships between money balances, income, and interest margin in the long run when measures of economic uncertainty were added to the system. Bulut and Karasoy [28] examined the transfer of policy decisions to financial markets in times of increasing or decreasing uncertainty in monetary policy. Bulut and Karasoy [28] used a case study of Turkey to analyze the period from June 2010 to January 2015. They measured monetary policy uncertainty with the CBRT Expectations Survey. Empirical findings are closely related to the policyrelated uncertainty of the monetary policy transmission mechanism. For example, the surprise policy rate increase causes the Turkish lira to appreciate against the US dollar in an environment of low uncertainty and to depreciate under high 
uncertainty. Aye [29] examines whether economic policy uncertainty (EPU) data in eight developing economies (Brazil, Chile, China, India, Ireland, Russia, South Africa, and South Korea) impact actual housing revenues. The study employs the cross-sample validation (CSV) Granger causality approach. The results based on the CSV illustration do not show any evidence that economic policy uncertainty leads to actual housing returns except in Chile and China. Wang et al. [30] used the Economic Policy Uncertainty Index and several Chinese macroeconomic datasets from 1999 to 2014. Thus, they analyzed the impact of macroeconomic variables on housing price volatility under different policy uncertainty regimes. They used a 'logistic seamless transition vector autoregressive model' and a generalized impulse response function. As a result, policy uncertainty in macroeconomics leads to an increase in housing prices.

Moreover, under different policy uncertainty regimes, macroeconomic shocks have an impact on housing price volatility. During high policy uncertainty, an expansionary monetary policy facilitated the increase in house prices; a tight monetary policy leads to a 'House Price Puzzle' that makes it difficult for house prices to stabilize. Thanh et al. [31] create a new measurement of uncertainty peculiar to the real estate sector from 1970M7 to 2017M12. They show double housing prices when the Real Estate Uncertainty (REU) measurement is compared with Macro Uncertainty (MU). Vector autoregressions and Granger-causality analysis results also show that uncertainty measurement impacts housing starts and prices. Aye et al. [32] examine the spillover effects of economic uncertainty in 12 OECD countries, the booming and decreases in the housing sector. They found that declines in the housing market increase statistically more with economic uncertainty than with a discrete-time duration (hazard) model.

The results show that housing has a possible protective task against uncertainty. Andre et al. [33] analyze whether economic policy uncertainty (EPU) in the USA predicts the actual housing revenue moves. They see that EPU impacts both actual housing returns and fluctuations. Namely, EPU leads to an uneven fall in housing returns. Çepni et al. [34] research the role of uncertainty peculiar to real estate to estimate the conditional distribution of USA housing sales growth in the 1970:07-2017:12 period based on Bayesian Model Average (BMA). They finally found that the real estate uncertainty decreases the housing sales growth. Gupta et al. [35] analyze the role of macroeconomic uncertainty to estimate the synchronization in housing price movements in the 1975:02-2019:12 period in the USA and the District of Columbia (DC). Bayes used the dynamic factor model and machine learning approach for random forests and found that macroeconomic uncertainty has a predictive effect on national factor (stochastic) fluctuation and total USA housing prices. Previous studies have examined the effect of uncertainties in economies on macroeconomic variables or whether international real estate investment is based on real estate prices and exchange rate levels. This study however, contributes to the literature as one of the detailed studies measuring foreigners' direct real estate investments under conditions of uncertainty in the economy.

\section{3- Research Methodology}

In the study, Poland, Greece, Slovak Republic, Hungary, Turkey, and Slovenia's uncertainty indices in the 20082018 period and foreign direct real estate investments in these countries were examined. Assuming a cross-sectional dependency between units in the study, second-generation unit root and cointegration tests were performed. Accordingly, the Cross-Sectional Augmented Dickey-Fuller (CADF) test was used to determine whether the series is constant or not; CADF was generalized with cross-section, to consider the effects of cross-section dependence. The CADF test extends ADF regression with the first differences of individual series and cross-sectional mean of lag levels. Stability in countries with the CADF test statistics is tested using the same test for each country. Moreover, with the CIPS statistics obtained by taking the country averages, a stationarity test is made for the panel in general [36]. The following flowchart illustrates the econometric methodology followed in this paper.

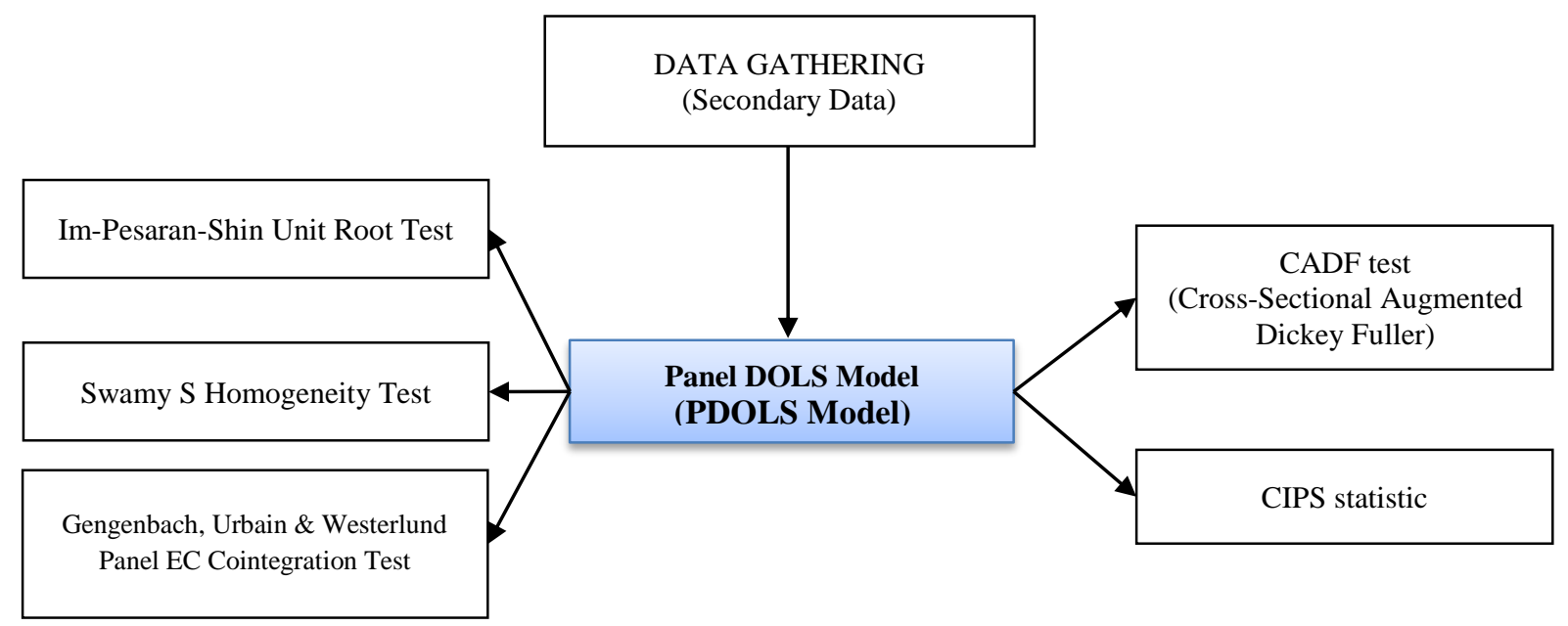

Figure 1. Flowchart of the research methodology. 
If a long-term relationship is found between series of variables, long-term parameters can be estimated using the Panel Dynamic OLS (PDOLS) method. The PDOLS Estimator is obtained by estimating the regression established using the values of the preceding and lagged variables of the differentiated I (1) variables. The PDOLS is a method that eliminates deviations in static regression by including dynamic elements in the model [37]. The most important advantages of the group-mean panel DOLS estimation technique, an intergroup estimator, compared to the in-group panel DOLS estimation methods, are that it causes fewer scale distortions and provides better predictions than those given by cointegration vectors with a heterogeneous structure. Therefore, in the study, the PDOLS estimation method was used to estimate the long-term coefficients of the variables. The expanded cointegration equation for PDOLS estimation can be expressed as follows [38].

$$
\text { fdire }_{i t}=\alpha_{i}+\beta_{i} w u i_{i t}+\sum_{j=-K i}^{K i} \gamma_{i k} w u i_{i t-k}+\mu_{i t}
$$

Where: fdire: Foreign Direct Real Estate Investment; wui: World Uncertainy Index; $\alpha, \beta, \gamma$ : Parameters of the model; $i$ : units; $t$ : Time period; and $\mu$ : Random error.

\section{4- Results and Discussion}

In this context, foreign real estate investments countries assumed to have high economic uncertainties in Europe such as Poland, Greece, Slovak Republic, Hungary, Turkey, and Slovenia have been examined in the study. The uncertainty index of these countries for the years 2008-2018 is shown in Figure 1.

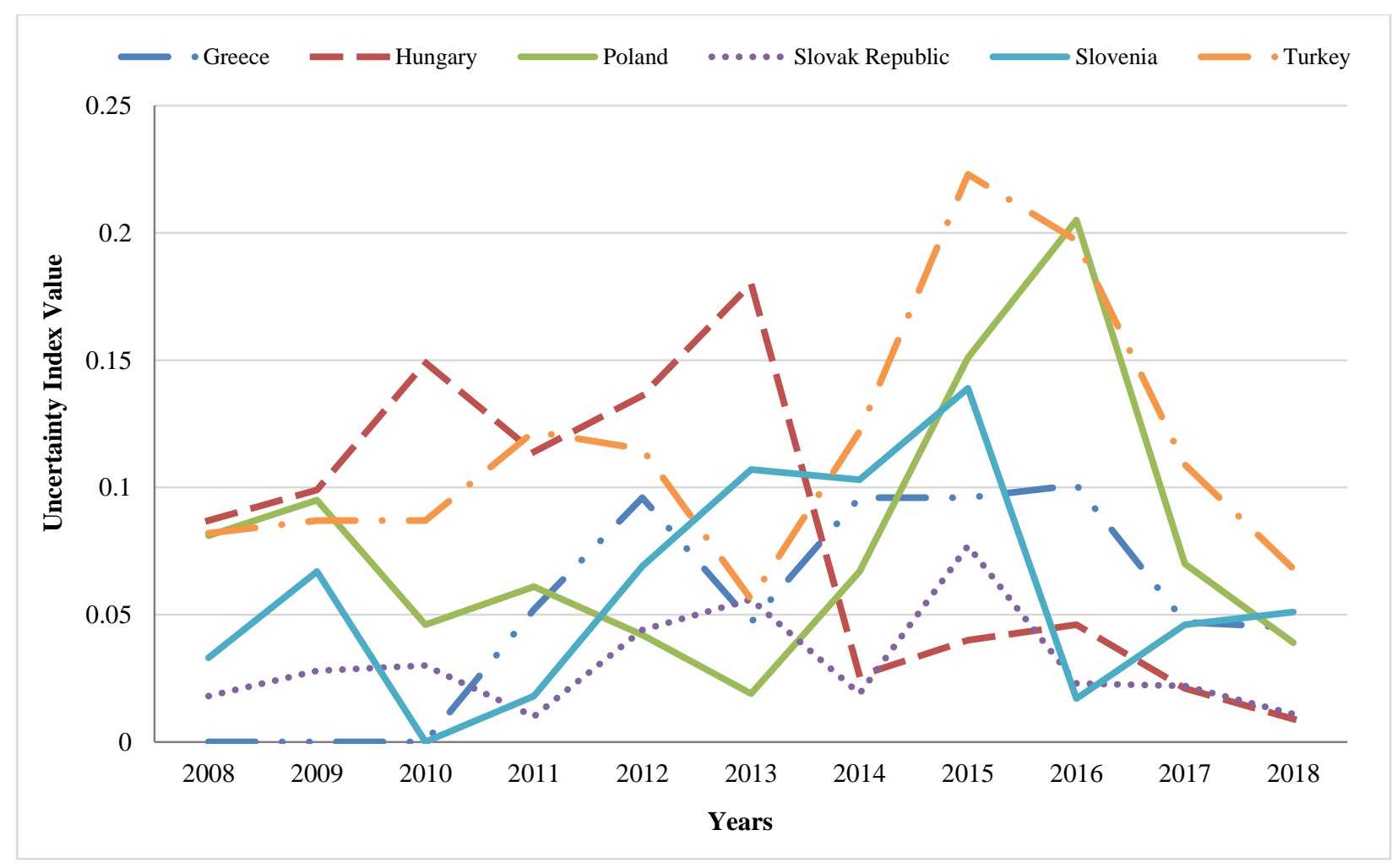

Figure 2. Uncertainty Index in Selected EU Countries (2008-2018) [39].

Uncertainty in developing countries generally follows an unstable course. While the uncertainty index in Turkey increased in the period 2013-2015, it declined after 2016. The uncertainty index rose sharply in Poland in the years 2013 - 2016 but has been declining since 2017. In Slovenia, the uncertainty index increased in 2010 - 2015, decreased in 2016, and started to increase in 2017. The uncertainty index in Hungary has been decreasing since 2013; while it follows a fluctuating course in Greece and Slovakia.

In the study, the analyses mentioned in the method are applied. First, Im-Pesaran-Shin Unit Root Test results are introduced accordingly. Second, Swamy S Homogeneity test results and Gengenbach Urbain \& Westerlund Panel EC Cointegration Test Results are presented. Finally, Panel DOLS results are demonstrated, and the results are discussed. 


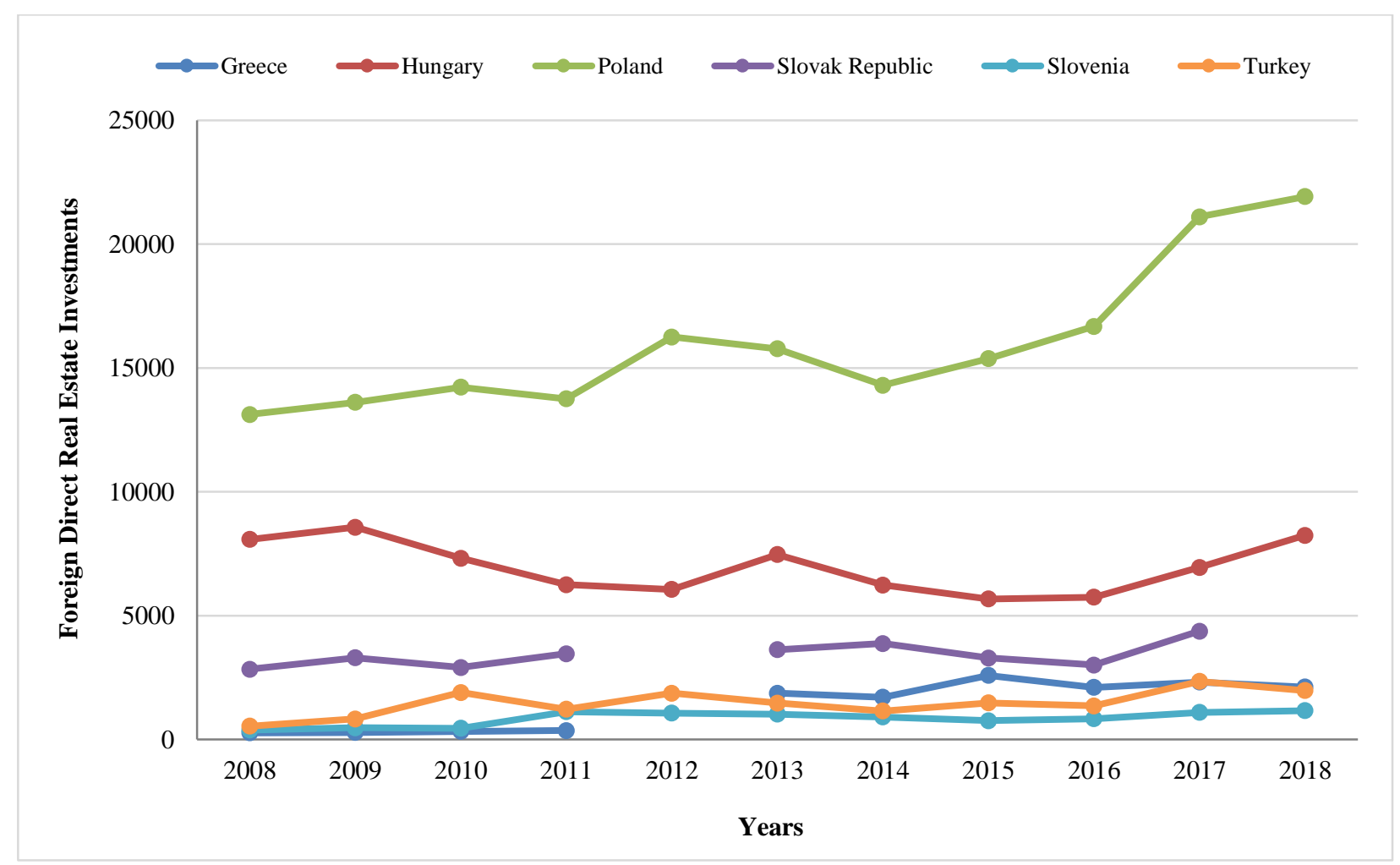

Figure 3. Foreign Direct Real Estate Investments in Selected EU Countries (2008-2018) (Million \$) [40].

Table 1. Im-Pesaran-Shin Unit Root Test.

\begin{tabular}{ccccc}
\hline \multirow{2}{*}{ Variables } & \multicolumn{2}{c}{ Level } & \multicolumn{2}{c}{ Difference } \\
\cline { 2 - 5 } & t-bar & P-value & t-bar & P-value \\
\hline fdire & -2.162 & 0.155 & -2.655 & 0.040 \\
wui & -2.202 & 0.177 & 2.610 & 1.000 \\
\hline
\end{tabular}

According to Table 1, the series is not constant at their level. When the differences are taken, the series is constant at the $5 \%$ significance level.

The homogeneity of the model was determined using the Swamy S test. According to the findings in Table 2, since the probability value is greater than the 'chi2' value, the hypothesis is rejected. This situation shows that the model is heterogeneous. In this case, it is appropriate to rely on the results of heterogeneous cointegration tests and to use the suggested estimation methods for heterogeneous panels [41]. As a result of the tests, a second-generation panel data analysis was deemed necessary.

Table 2. Swamy S Homogeneity Test Results.

\begin{tabular}{|c|c|c|c|c|c|c|}
\hline fdire & Coef. & Std. Err. & $\mathbf{Z}$ & $\mathbf{P}>|\mathbf{z}|$ & $95 \%$ Conf. & Interval \\
\hline wui & 2.741609 & 3.038926 & 0.90 & 0.367 & -3.214578 & 8.697795 \\
\hline \multirow[t]{2}{*}{ _cons } & 7.749759 & .5842644 & 13.26 & 0.000 & 6.604622 & 8.894896 \\
\hline & Test of $p$ & $r$ constancy: & $\operatorname{chi} 2(10)=907.88$ & Prob $>$ & 0000 & \\
\hline
\end{tabular}

Based on the results of the Swamy S Homogeneity Test results, the hypothesis was rejected as the parameters were heterogeneous. The Panel Cointegration Analysis is performed using the Gengenbach, Urbain \& Westerlund Panel EC Cointegration Test [42] in line with the obtained results and assumptions of inter-unit correlation and heterogeneity.

Table 3. Gengenbach, Urbain \& Westerlund Panel EC Cointegration Test.

\begin{tabular}{cccc}
\hline d.y & Coef & T-bar & P-value* $^{*}$ \\
\hline$y(t-1)$ & -0.938 & -4.078 & $<=0.01$ \\
\hline
\end{tabular}

Since p-Value $<0.01 H_{0}$, the hypothesis was rejected. There is a cointegration relationship between the uncertainty index and foreign direct real estate investments. 
Table 4. Panel DOLS Results.

\begin{tabular}{ccc}
\hline \multicolumn{3}{c}{ Lags and leads: 1} \\
\hline Number of obs: 48 \\
\hline Variable & Coefficient & t-stat \\
\hline wui & 5.731 & 10.21 \\
\hline
\end{tabular}

According to Table 4, there is a relationship between the uncertainty index and foreign direct real estate investments for the panel as a whole. According to the PDOLS results, the $1 \%$ increase in the uncertainty index in the analyzed countries increases foreign direct investments by $5.731 \%$.

\section{5- Conclusions}

Uncertainties in economic policies are an essential source of instability for the macroeconomy in general. Uncertainties are particularly effective on investments in the real estate market for the economies of underdeveloped and developing countries.

This situation can be explained as follows; high economic uncertainty in developing countries causes the exchange rate to rise. The increase in the exchange rate results in relatively low real estate prices in developing countries, making the country attractive for foreign investors in real estate. Thus, relatively low real estate prices increase foreigners' direct real estate investments in developing countries.

Foreign direct real estate investments to European countries namely, Poland, Greece, Slovak Republic, Hungary, Turkey, and Slovenia that are assumed to have uncertainties in the economy have been examined. There is a long-term relationship between the uncertainty index and direct foreign real estate investments for the panel. According to the PDOLS results, the $1 \%$ increase in the uncertainty index in the analyzed countries increases foreign direct investments by $5.731 \%$. Empirical results show that uncertainty increases foreigners' direct real estate investments, contrary to the expectation that foreigners will reduce their direct real estate investments.

The uncertainty in the Greece economy increased after the 2008 global crisis due to the debt crisis; and policymakers thereafter aimed to increase direct foreign investment to overcome the economic crisis. It is assumed that foreigners invested, especially in Greek islands. After the 2008 global crisis, real estate sales to foreigners in Turkey were unleashed. The currency increase in Turkey after 2014 lead to an increase in foreigners' real estate investments. Also, since the other examined developing countries have similar economic features, foreigners' real estate investments in those countries increased.

However, to increase foreigners' direct real estate investments in a sustainable way in developing countries, economic and political stability should be prioritized. This is because macroeconomics, risks that may arise from the real estate market are also limited when economic and political stability is achieved. Facilitating the bureaucratic process, providing tax reductions, making real estate suitable for demand, following the appropriate price policy, and making various environmental regulations will also increase foreigners' direct real estate investments.

\section{6- Declarations}

\section{6-1-Data Availability Statement}

The data presented in this study are available on request from the corresponding author.

\section{6-2- Funding}

The author received no financial support for the research, authorship, and/or publication of this article.

\section{6-3-Ethical Approval}

The participant gave his written consent to use his anonymous data for statistical purposes. The participant was over 18 years old and voluntarily collaborated without receiving any financial compensation.

\section{6-4- Conflicts of Interest}

The author declares that there is no conflict of interest regarding the publication of this manuscript. In addition, the ethical issues, including plagiarism, informed consent, misconduct, data fabrication and/or falsification, double publication and/or submission, and redundancies have been completely observed by the author. 


\section{7- References}

[1] Özden, Miray, and Ertuğrul Recep Erbay. "Küresel Vatandaşlık: Belirsizlik Mi, Fırsat Mı?." Social Sciences Research Journal 7, no. 4 (2018): 76-81.

[2] Çiftçi, A. and Arı, Y. “Antalya İlinde Yabancılara Satılan Konut Sayısı Üzerine Bir Eşbütünleşme ve VECM Analizi.” 6. Uluslararası Sosyal, Beşeri ve İdari Bilimler Sempozyumu, Alanya, Türkiye, 18-20 (April 2019): 479-488.

[3] Özaktaş, F. D. 'YYabancılara Konut Satış1 ve Reel Efektif Döviz Kuru: Türkiye Örneği Ampirik Çalışma.' Ekonomik ve Sosyal Araştırmalar Dergisi 15 no. 1 (2019): 131-147.

[4] Sarıtaş, T. “Türkiye'de Turizmin Yabancılara Yapılan Konut Satışlarına Etkisi.’’ Balkan ve Yakın Doğu Sosyal Bilimler Dergisi, Special Issue (2020): 94-100.

[5] Bolat, M. and Şenol, L. “'International Marmara Social Sciences Congress (Autumn).'” Kocaeli, Turkey, 4-5 December 2020, 214-219.

[6] Darıcı, B. "Para Politikası ve Konut Fiyatları İlişkisi: Türkiye Ekonomisi için Ampirik Bir Analiz." Anemon Muş Alparslan Üniversitesi Sosyal Bilimler Dergisi, Special Issue on International Conference on Empirical Economics and Social Science (ICEESS'18) (2018): 221-228.

[7] Çetin, Mümin Atalay, İlker Yaman, and İbrahim Bakirtaş. "Reel Konut Fiyatları Ile Ekonomi Politikaları Belirsizliği Arasındaki İlişki: Güney Kore Örneği.” Recep Tayyip Erdoğan Üniversitesi Sosyal Bilimler Dergisi 11, (June 29, 2020): 114-144. doi:10.34086/rteusbe.732041.

[8] Demirgil, H. “'Politik İstikrarsızlık, Belirsizlik ve Makroekonomi: Türkiye Örneği (1970-2006).’’ Marmara Üniversitesi İ.İ.B.F. Dergisi 31, no. 2 (2011): 123-144.

[9] Korkmaz, Özge, and Selim Güngör. "Küresel Ekonomi Politika Belirsizliğinin Borsa İstanbul'da İşlem Gören Seçilmiş Endeks Getirileri Üzerindeki Etkisi." Anemon Muş Alparslan Üniversitesi Sosyal Bilimler Dergisi 6, no. ICEESS'18 (2018): 211-219. doi:10.18506/anemon.452749.

[10] Süleymanl1, Cavid. "Türkiye’de Yabancıların Konut Edinimi İle Döviz Kuru Arasındaki İlişki: Eşbütünleşme Analizi (20132019).” Bingöl Üniversitesi İktisadi Ve İdari Bilimler Fakültesi Dergisi 3 no. 2 (December 31, 2019). doi:10.33399/biibfad.595840.

[11] Pilvere-Javorska, Aija, and Irina Pilvere. “European Nordic Countries Stock Market Listed Companies': Factor and Cluster Analysis Approach.” Emerging Science Journal 4, no. 6 (December 1, 2020): 443-453. doi:10.28991/esj-2020-01244.

[12] Gerlowski, Daniel A., Hung-Gay Fung, and Deborah Ford. "The Location of Foreign Direct Investment for US Real Estate: An Empirical Analysis." Land Economics (1994): 286-293.

[13] Cheng, Ping, Alan Ziobrowski, Royce Caines, and Brigitte Ziobrowski. "Uncertainty and Foreign Real Estate Investment." Journal of Real Estate Research 18, no. 3 (January 1, 1999): 463-479. doi:10.1080/10835547.1999.12091002.

[14] Miles, William. "Irreversibility, Uncertainty and Housing Investment." The Journal of Real Estate Finance and Economics 38, no. 2 (September 21, 2007): 173-182. doi:10.1007/s11146-007-9087-x.

[15] Rodríguez, Carlos, and Ricardo Bustillo. "Modelling Foreign Real Estate Investment: The Spanish Case.” The Journal of Real Estate Finance and Economics 41, no. 3 (December 4, 2008): 354-367. doi:10.1007/s11146-008-9164-9.

[16] Gholipour Fereidouni, Hassan, and Ebrahim Bazrafshan. “Determinants of Returns on Housing: The Iranian Case.” International Journal of Housing Markets and Analysis 5, no. 4 (September 28, 2012): 351-360. doi:10.1108/17538271211268493.

[17] Salem, Mohamed, and Andrew Baum. "Determinants of Foreign Direct Real Estate Investment in Selected MENA Countries." Journal of Property Investment \& Finance 34, no. 2 (March 7, 2016): 116-142. doi:10.1108/jpif-06-2015-0042.

[18] Rogers, Dallas, and Sin Yee Koh. "The Globalisation of Real Estate: The Politics and Practice of Foreign Real Estate Investment.” International Journal of Housing Policy 17, no. 1 (January 2, 2017): 1-14. doi:10.1080/19491247.2016.1270618.

[19] ŞİT, Mustafa. “The Determinants of Foreign Direct Investments in Real Estate: Turkey Case.” The Journal of Social Sciences Research no. 53 (March 28, 2019): 789-795. doi:10.32861/jssr.53.789.795.

[20] Johnson, Robert, Colin Lizieri, Luc Soenen, and Elaine Worzala. "Simulating Currency Risk on Private Investments in Real Estate." Journal of Real Estate Portfolio Management 12, no. 2 (January 1, 2006): 91-102. doi:10.1080/10835547.2006.12089751.

[21] Addae-Dapaah, Kwame, and Wilfred Tan Yong Hwee. "The Unsung Impact of Currency Risk on the Performance of International Real Property Investment." Review of Financial Economics 18, no. 1 (January 2009): 56-65. doi:10.1016/j.rfe.2008.04.002.

[22] Choi, Changkyu, and Kyungsun Park. "Does the Euro Increase FDI in the Real Estate Industry? Evidence from the German Case.” Journal of European Real Estate Research 5, no. 1 (May 4, 2012): 88-100. doi:10.1108/17539261211216021. 
[23] Gholipour Fereidouni, Hassan, and Tajul Ariffin Masron. "Real Estate Market Factors and Foreign Real Estate Investment." Journal of Economic Studies 40, no. 4 (August 30, 2013): 448-468. doi:10.1108/jes-05-2011-0066.

[24] Gholipour Fereidouni, Hassan, Al-mulali Usama, and Abdul Hakim Mohammed. "Foreign Investments in Real Estate, Economic Growth and Property Prices: Evidence from OECD Countries." Journal of Economic Policy Reform 17, no. 1 (January 2, 2014): 33-45. doi:10.1080/17487870.2013.828613.

[25] Wokker, C. and Swieringa, J. “Foreign Investment and Residential Property Price Growth.” Treasury Working Paper No. 201603.

[26] Rogers, Dallas, Alexandra Wong, and Jacqueline Nelson. "Public Perceptions of Foreign and Chinese Real Estate Investment: Intercultural Relations in Global Sydney." Australian Geographer 48, no. 4 (May 8, 2017): $437-455$. doi:10.1080/00049182.2017.1317050.

[27] Özdemir K. A. and Saygılı M. "Economic Uncertainty and Money Demand Stability in Turkey." Central Bank of the Republic of Turkey, (2010). Working Paper No: 10/15.

[28] Bulut, M. and Karasoy, H. G. “Para Politikası Belirsizliği Altında Aktarım Mekanizması: Türkiye Örneği.’” MPRA Paper No. 71215, (2016). Available online: https://mpra.ub.uni-muenchen.de/71215/ (accessed on March 2021).

[29] Aye, Goodness C. "Causality Between Economic Policy Uncertainty and Real Housing Returns in Emerging Economies: A Cross-Sample Validation Approach.” Edited by Wai Ching Poon. Cogent Economics \& Finance 6, no. 1 (January 1, 2018): 1473708. doi:10.1080/23322039.2018.1473708.

[30] Wang, Sen, Yanni Zeng, Jiaying Yao, and Hao Zhang. "Economic Policy Uncertainty, Monetary Policy, and Housing Price in China.” Journal of Applied Economics 23, no. 1 (January 1, 2020): 235-252. doi:10.1080/15140326.2020.1740874.

[31] Nguyen Thanh, Binh, Johannes Strobel, and Gabriel Lee. “A New Measure of Real Estate Uncertainty Shocks.” Real Estate Economics 48, no. 3 (December 12, 2018): 744-771. doi:10.1111/1540-6229.12270.

[32] Aye, Goodness C., Matthew W. Clance, and Rangan Gupta. "The Effect of Economic Uncertainty on the Housing Market Cycle.” Journal of Real Estate Portfolio Management 25, no. 1 (January 1, 2019): 67-75. doi:10.1080/10835547.2019.12090024.

[33] André, Christophe, Lumengo Bonga-Bonga, Rangan Gupta, and John W. Muteba Mwamba. "Economic Policy Uncertainty, U.S. Real Housing Returns and Their Volatility: A Nonparametric Approach.” Journal of Real Estate Research 39, no. 4 (October 1, 2017): 493-514. doi:10.1080/10835547.2017.12091484.

[34] Çepni, Oğuzhan, Rangan Gupta, and Mark E. Wohar. "The Role of Real Estate Uncertainty in Predicting US Home Sales Growth: Evidence from a Quantiles-Based Bayesian Model Averaging Approach.” Applied Economics 52, no. 5 (August 18, 2019): 528-536. doi:10.1080/00036846.2019.1654082.

[35] Gupta, Rangan, Hardik A. Marfatia, Christian Pierdzioch, and Afees A. Salisu. "Machine Learning Predictions of Housing Market Synchronization across US States: The Role of Uncertainty.” The Journal of Real Estate Finance and Economics (January 12, 2021). doi:10.1007/s11146-020-09813-1.

[36] Alev, N. and Erdemli, M. (2019). "Elektrik Enerjisi Tüketimi ve Ekonomik Büyüme İlişkisi: Avrupa Birliği Ülkeleri ve Türkiye İçin Bir Analiz.’’ ASSAM Uluslararası Hakemli Dergi, 6 no. 15 (2019): 66-85.

[37] Işık, Nalan. “Avrupa'da Sürdürülebilir Kalkinma, Büyüme Ve Turizm: Panel Veri Analizi.” International Review of Economics and Management (June 1, 2018): 1-17. doi:10.18825/iremjournal.365077.

[38] Ecevit, E., Çetin, M. and Yücel, A. G. “'Türki Cumhuriyetlerinde Sağlık Harcamalarının Belirleyicileri: Bir Panel Veri Analizi.'” Akademik Araştırmalar ve Çalışmalar Dergisi, 10 no. 19 (2018): 318-334.

[39] World Uncertainty Index (WUI). Available online: https://worlduncertaintyindex.com/data/ (accessed on 16 March 2021).

[40] OECD. Available online: https://read.oecd-ilibrary.org/finance-and-investment/oecd-international-direct-investment-statistics2019_g2g9fb42-en\#page1 (accessed on 18 March 2021).

[41] Alancıŏglu, Erdal, and Mustafa Şit. “Turizmde Beşeri Sermaye Gelişiminin Rolü: Turizme Bağımlı Ekonomiler İçin Panel Veri Analizi.” Turk Turizm Arastirmalari Dergisi 4, no. 2 (April 15, 2020): 1109-1122. doi:10.26677/tr1010.2020.385.

[42] Ünsal, M. E. " Geçiş Ekonomilerinde Hükümet Harcamaları ve Ekonomik Büyüme İlişkisi: Panel Eşbütünleşme ve Panel Nedensellik Analizleri." International Journal of Economics and Politics Sciences Academic Researches 4, no. 10 (2020): 2835 . 